\title{
TWENTY YEARS OF REFLECTIONS *
}

\author{
Aravind K. Joshi \\ Department of Computer and Information Science \\ R. 268 Moore School \\ University of Pennsylvania \\ Philadelphia, PA 19104
}

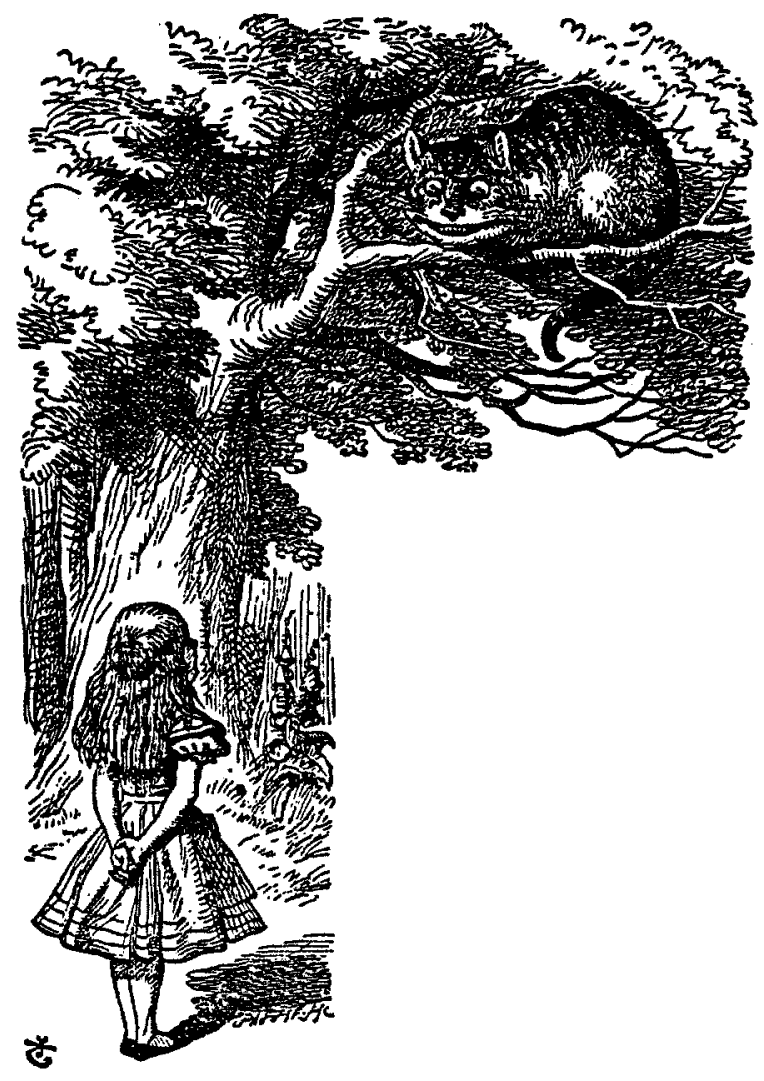

As I was reflecting deeply in front of the statue of Bodhisattva of Grammar and Wisdom in the University Museum, I was startled to see Jane. Having heard from Don that he had asked the old cats to reflect on the 20 years of ACL, Jane had decided that she should drop in on some of them to seek their advice concerming the future of ACL.

*This work is supported by the unfunded grant FSNRND-HIN-82-57. I wish to thank Alice, the Cheshire Puss, and Lewis Carroll for their help in the preparation of this paper.

"What brings you here?" I asked with a grin. Jane thought for a while and said:

"Would you tell me, please, which way I ought to take ACL in the future?"

"That depends a good deal on where you think it should go," I replied.

"I don't much care where, ," said Jane.

"Then it doesn't matter which way you take it," I said after prolonged reflection.

"_ so long as I take it somewhere," Jane added as an explanation.

"Oh, you are sure to do that," said I, "if you only parse long enough."

Jane felt that this could not be denied, so just to be friendly she decided to ask another question:

"What sort of computational linguists live about here?"

"Well, in that direction lives Bonnie," I said waving my right paw and waving the other paw, "and in that direction lives Barbara. Visit either you like:they're both mad."

"But I don't want to go among mad people," Jane remarked.

"Oh, you can't help that," said I, "we're all

mad here. I'm mad. You're mad."

"How do you know I'm mad?" said Jane.

"You must be," said I, "or you wouldn't have come here."

Jane didn't think that proved it at all. However, she went on: "And how do you know that you're mad?"

"Well, to begin with," said I, "Don is not mad. You grant that?"

"I suppose so," said Jane.

"Well, then," I went on, "Don is not mad and I am not Don. Therefore, I an mad."

Jane didn't appear to be satisfied with this bit of catatonic logic (quite distinct from the monotonic logic).

"I must go for a walk now and continue reflecting," I said, as I left her, leaving my grin behind. 